\title{
От географии для детей к географии детства: кейс Калининградской области
}

\section{Введение}

В современном мире повседневная жизнь человека и общества связаны с влиянием географрических фракторов на разных уровнях, начиная с глобального и заканчивая локальным, в том числе в области путешествий и отдыха. География помогает организовать пространственную жизнь общества, оказывает воздействие не только на природные, но и на хозяйственные, экономические и общественные объекты.

В условиях новых угроз и вызовов современной цивилизации географические знания помогают диагностировать и бороться с климатическими изменениями, загрязнениями окружающей среды, повышать качество жизни населения, улучшать среду обитания, а также вовлекать взрослых и детей в решение вопросов ее преобразования.

Географическая наука тесно связана с решением практических задач и является важной частью образовательного процесса. Согласно Концепции развития географического образования в Российской Федерации, качественное географическое образование призвано обеспечивать: форммирование гражданской идентичности, патриотизма, экологической грамотности и социальной ответственности, расширенный кругозор и развитие пространственного мышления; заложить основу для подготовки будущих специалистов в областях географических и смежных наук, обучение владением информационно-коммуникационных технологий, необходимых в повседневной жизни (систем глобального позиционирования, электронных карт и геоинформационных систем) [9].

Основными социальными институтами, осуществляющими географическое образование современного ребенка-подростка-молодого человека, выступают школа и соответствующие профильные высшие и среднеспециальные учебные заведения. Дополнительной площадкой становится деятельность естественнонаучных музеев и кружков, географических мероприятий, библиотек и пр. В образовавшейся системе взаимодействий происходит популяризация географической науки, повышается значимость географического образования детей и молодежи для их повседневной жизни. Методисты в области географического образования отмечают важность внеклассной работы в форматах әкскурсионно-краеведческой работы, научных конференций, географических олимпиад, тематических вечеров и пр. для включенности школьников в природную и социальную среды, формирование ответственного отношения

\section{(C) Филипова А. Г., Зубова О. Г., Бухтиярова И. Н., 2021}

ФИЛИПОВА Александра Геннадьевна, д-р социол. наук, доцент Владивостокского государственного университета экономики и сервиса, заведующий лабораторией комплексных исследований детства, старший научный сотрудник Российского государственного педагогического университета им. А.И. Герцена (г. Владивосток). E-mail: alexandra.filipova77@gmail.com

ЗУБОВА Оксана Геннадьевна, канд. полит. наук, доцент кафедры социальных технологий Московского государственного университета им. Ломоносова (2. Москва). E-mail: zubovaoksana@ bk.ru

БУХТИЯРОВА Ирина Николаевна, канд. пед. наук, старший преподаватель кафедры истории и теории социологии Московского государственного университета им. Ломоносова (2. Moсква). E-mail: ira_irina@mail.ru 
к ним, а также для создания условий для непрерывного географического образования [12, 13].

Активно развивающаяся за рубежом география детства также может стать источником "оживления" географии, развития познавательного интереса детей к географической науке, поскольку ее объектом являются пространственные взаимодействия и пространственное поведение детей $[\mathbf{1 7}, \mathbf{2 0 , 2 6 ]}$.

Зарубежные исследователи пытаются развести понятия "место" (place) и "пространство" (space), рассматривая последнее как "вместилище для природных и социальных событий", а место как "именованное пространство". Места обретают смысл через действие человека, через жилище, через эмоциональные привязанности, через события и через связанные с ними воспоминания. Иногда эти понятия противопоставляются друг другу, так, например, для географов-гуманистов 1970-х гг. "место" стало отправной точкой исследований, противопоставляемой "объективным", "мертвым", позитивистским представлениям о пространстве [21].

Детский опыт проживания разных пространств существенно отличается от опыта взрослых. В рамках исследовательского проекта "Vertical Living Kids" были проведены беседы с детьми в возрасте 8-12 лет с целью выяснения их взглядов на местную среду, выявлены существенные расхождения со взглядами взрослых [27].

Ориентирами географии детства выступают признание положения детей в обществе, их права на надлежащее исследование, изучение уникальных жизненных миров [22], осмысление вклада в более широкие географические теории. Однако преподавание географии в школе тяготеет к "объективности", к изложению фактов без "оживления" данных, установления связи с живым опытом, окружающим детей миром [24]. В публикации Сьюзан Пайк представлен анализ дефинищий географии учащимися ирландской начальной школы. Исследователь отмечает оторванность в детских определениях географрической науки и реального опыта: "... более половины детей определили географрию как относящуюся к темам и местам. Четкий акцент на изучение названий мест и изучение фактов был сделан в определениях... Навыки, за исключением "карт", упоминали немногие дети. Ни один ребенок не говорил о работе на местах" [23].

Т. Сэк и Дж. Петерсон, сравнивая отношение детей к географии как к школьному предмету в 1983 и 1993 гг. в Сан-Маркосе (штат Техас), пришли к заключению, что, хотя в среднем дети считали географию своим наименее любимым предметом в общем списке школьных предметов, фриксируется некоторое статистически значимое улучшение популярности географии за рассматриваемое десятилетие. Исследователи связывают это изменение с использованием более активных сред обучения [25].

В новой области - музейной географии детства - последовательно продвигается идея отхода от традиционного представления о музеях как о площадках, где дети предстают в обучающихся и повествующих ролях, в сторону развёрнутого понимания детей как носителей опыта и игры [19].

Субъектные позиции ребенка в обществе, на уроках географии, в родной семье взаимосвязаны и одинаково важны. Недооценивание детской активности, восприятие ребенка как объекта педагогического/ сощиализирующего воздействия взрослых в нашей стране привело к существенному запаздыванию институционального оформления социологии детства и полному отсутствию географии детства как междисциплинарного направления, сформировавшегося на стыке гуманитарной географии и социальных исследований детства [8]. Справедливости ради нужно заметить, что игнорирование географии детства связано с развитием географической науки в советский период, когда акценты с индивидуального развития (культурной географии, гуманитарной географии) были смещены в сторону развития экономики, промышленного комплекса, освоения природных ресурсов и т.п. [11].

В то же время за рубежом геоградия детства имеет уже довольно длительную историю развития $[14,16,18]$.

Для того, чтобы изучить интерес общества к теме географии детства, использовался сервис Google Trends, в котором анализируется статистика пользовательских запросов в поисковой системе Google. В итоговой инфографике представлено отношение количества запросов ключевых слов к общему 
количеству запросов в регионе за определенный отрезок времени, итоговые данные представлены 100-бальной шкалой, в которой 100 баллов отведено самому высокому показателю.

Статистика поисковых запросов с использованием словосочетаний "geography of children", "child geography" и "geography for children" в GoogleTrends за последние 5 лет показывает, что наибольшее количество запросов приходится на март 2019 г., преимущественно интерес к данной проблематике проявляют жители США, Индии, Великобритании, Канады, Австралии. По России запросов по данным ключевым словосочетаниям, а также по словосочетанию "география детства" мало, и они не визуализируются (puc. 1).

Таким образом, можно констатировать усиление внимания мировой общественности к географическим знаниям, в т.ч. в плоскости ориентации географической науки на детей, также можно констатировать укрепление позищии географии детства как междисциплинарного исследовательского направления.

Целью настоящего исследования является рассмотрение перехода от географии для детей к географии детства на примере учреждений и практик популяризации географических знаний в Калининградской области.

Калининградская область является самой западной территорией России. На севере и востоке область граничит с Литовской республикой, на юге - с Польшей, на Западе омывается Балтийским морем. Города и поселки связаны густой сетью транспортных коммуникаций в единый хозяйственный комплекс [10].

В Калининградской области потребность в географических знаниях определяется спецификой географического положения: расположение на юго-восточном побережье Балтийского моря, незамерзающее побережье, близость к Атлантическому океану и основным торговым партнерам, соседство с экономически высокоразвитыми странами, богатые месторождения янтаря (одно из крупнейших в мире), глин, гравия, каменной соли и других, благоприятные природные условия, всё это создает предпосылки для развития океанического рыболовства, торговли, туризма, добычи природных ископаемых.

\section{Материалы и методы исследования}

Для сбора эмпирических данных были определены две локации - Музей Мирового океана и Балтийский фредеральный университет.

$\mathrm{C}$ целью популяризации географических знаний, географической подготовки школьников и профориентационной работы с потенциальными абитуриентами в БФУ в 2015 г. была создана Географическая школа Калининградского отделения Русского Географического общества. Контингент учащихся составляют школьники 7-11 классов г. Калининграда и Калининградской области.

Также с 2015 г. в БФУ проводится географический фестиваль. Согласно Положению о фестивале его задачами являются выявление, поддержка и профрессиональная ориентация одаренных детей и молодежи, развитие и повышение качества профильного географического образования, реализация просветительских проектов.

Всего было проведено 4 географических фрестиваля: "Калининградская область - западный географический форпост России: вчера, сегодня, завтра" (2015 г.), "Земля - наш дом: изучаем, путешествуем, охраняем" (2017 г.), "Горизонты географиии XXI в.: взгляд в прошлое, настоящее и будущее" (2018 г.), "Балтийский регион России в XXI в.: траектории экономического, демографического и территориального развития" (2019 г.).

Методами сбора данных в двух обозначенных локациях стали экспертные интервью со специалистами Музея Мирового океана, преподавателями географической школы и организаторами географического фестиваля $(\mathrm{N}=7)$, групповые интервью со школьниками и студентами $(\mathrm{N}=21)$, метод анализа документов (положений, отчетов и пр.), анкетирование учителей $(\mathrm{N}=21)$ и детей-участников географического фестиваля $(\mathrm{N}=34)$.

Методами анализа эмпирических данных стало осевое кодирование (по Страусс и Корбин) [7]. Были выделены коды: востребованность географических знаний; принципы и методы организации работы с детьми разных воз- 


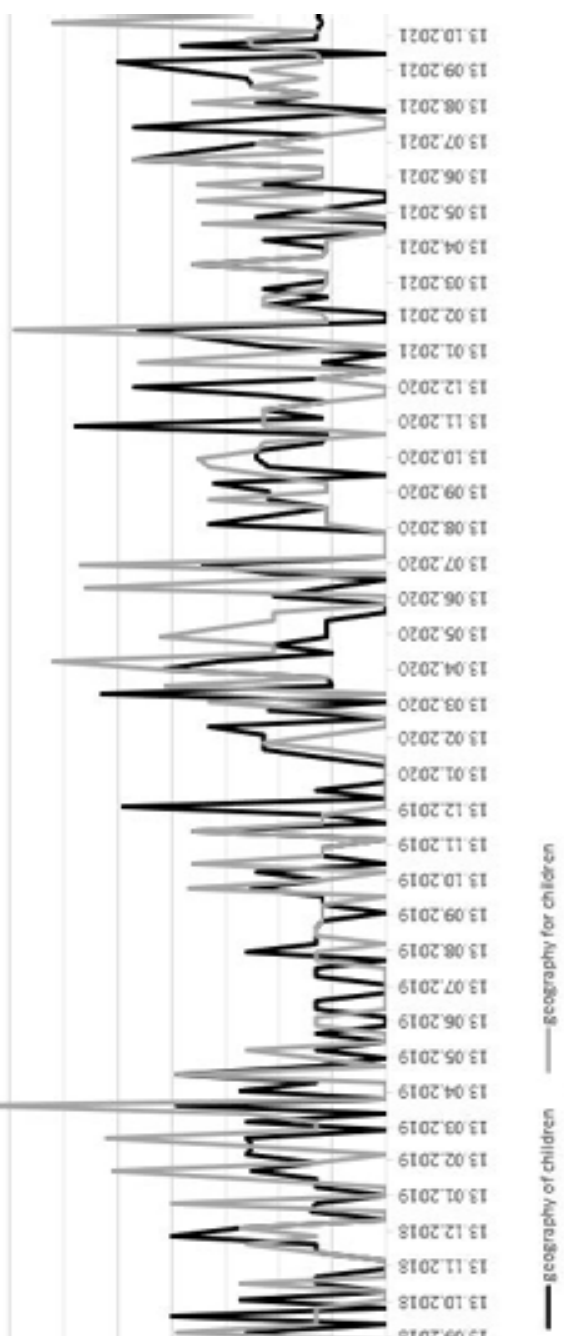


растов и взрослыми (учителями, родителями); интерактивные технологии; научно-исследовательская работа со школьниками; популяризация географической науки в регионе; география детства.

\section{Результаты и их обсуждение Почему дети не бредят подвигами полярников?}

Почему детям не интересна география, почему они "не бредят подвигами полярников", как это было раньше. Во-первых, это изменившийся географический мир, основательно изученный, в котором уже сделано достаточно географических открытий. Во-вторых, увеличивающийся разрыв между педагогами и учениками, вызванный среди прочих оснований сощиально-экономическим неравенством. Случается так, что ученики много путешествуют и наблюдают разные географические объекты вживую в отличие от учителей географии. В-третьих, это доступность географических знаний. Интернет-среда не оставляет секретов для детей, которые могут посмотреть фильм на National Geographic, попутешествовать с героями "Орла и решки", поискать информацию в Википедии и т.п. Все доступно, красочно и интересно. На таком контрасте школьные уроки географии выглядят скучными и малопривлекательными:

" ... я полню, как нал преподавали географбию, и, если честно, не особо любила этот предлет. У нас так бьло, что мы приходили, нал давали какую-то работу, мы ее делали, получали оценки, уходили. У нас не бьло взаилодействия между ученикали. Такие бьли работы - напишите конспект, заполните карту" (студентка БФУ, 1 курс, география).

Конечно, проблема мотивации к школьному обучению - это общая проблема российской школы. Возникающие прорывы в виде увлеченности обучающихся отдельными предметами в школе чаще всего бывают связаны с личностью педагога, в т.ч. учителя географиии. Поэтому неслучайно более половины школьников-участников четвертого географического фрестиваля в ходе анкетного опроса отметили, что именно школьный учитель географии повлиял на их увлечение географией. Иногда респонденты не указывали напрямую учителя, а говорили о школьных уроках географии, а один раз - об уроках истории.

В-четвертых, необходимо отметить разрыв связи географической науки с практикой и повседневной жизнью, с другими школьными предметами, что актуализирует поиск новых методик и подходов в обучении [6].

Из интервью со школьниками становится ясно, что они не понимают связи изучаемых тем с их практической пользой: "некоторые телы не особенно полезны, например, расположение полезных ископаемых. Это интересно только тел, кто собирается связывать с геограббией свою жизнь" (м, 16). Поэтому в ходе интервью ребятам было сложно вспомнить интересные уроки географии в школе. В редких случаях, о которых иногда говорили школьники, эти уроки связывались с краеведением и какими-то экскурсиями, походами, ориентированием на местности и пр.

По мнению учащихся, географические знания нужны современному человеку, чтобы "шире слотреть на лир, не залькаться в своей стране, области, борлировать сознание гражданина лира" (ж., 17), а также "для путешествий с сельей и друзьяли" (ж., 16), развития своего края и внутреннего туризма.

Именно благодаря проектам по развитию своего края и экологической деятельности, многие учащиеся по-другому начинают воспринимать географию, понимая ее роль и значение в их жизни, в развитии их территории проживания. Неслучайно весомая доля проектов, с которыми выступают дети на географическом фестивале в Калининграде, имеют социально-экономическую направленность. В 2015 г. из 10 представленных на конкурс проектов, только один, а в 2019 г. из 23 проектов только 8 были связаны с фризической географией.

Темы проектов выбираются не только по инициативе учителя, но и под влиянием интересов самих школьников, связанных с сохранением, изучением и улучшением территории проживания. Из интервью с победителями географического фестиваля 2019 г.: "Наш проект связан с историей нашего города-Гусева. К этолу проекту мы пришли, ль с учителел поговорили, 
он нас сподвиг, миь сали заинтересовались узнать лучше историю нашего города" (м., 16).

В реализации проектов школьникам помогает не только их руководитель - учитель географии, но и поддержка семьи, друзей, работников музея, научных работников, заинтересованных в проекте пользователей из социальных сетей. Как отмечали школьники-участники географического фестиваля, основная сложность подготовительного этапа заключалась в недостоверности информации интернет-ресурсов, проблема компенсировалась использованием библиотек города, школьной библиотеки, архивов, встречами с экспертами, работой в музеях, в том числе проведение необходимых анализов проб в лабораториях.

Хотя многие школьники, участники и победители фрестиваля, не стремятся связывать свою будущую профессию с географией, они тем не менее хотели бы продолжить свои проекты: "мне бы в моел проекте хотелось бы увеличить масштаб участков, с которых была взята проба" (м., 16); "мьь планируел с учителел экскурсию для наших школьников по всел представленныли скульптурал, потолу что по опросал учащихся мы поняли, что очень малое количество людей знают шуточные скульптуры и их видели в нашем городе" (ж., 15); "мой проект достаточно важный и значилый, я хотела бы охватить гораздо большую территорию и даже вывести какой-то способ очищения" (ж., 15).

Участники географического фестиваля понимают важность и актуальность своих проектов, стремятся предложить мероприятия для улучшения экологической и социально-экономической ситуации в Калининградской области, привлечь внимание общественности к решению существующих проблем, в т.ч. через обращение в региональные и муниципальные органы власти.

\section{География для детей}

Как география может сделать жизнь детей интереснее и увлекательнее? Обозначенные нами локации с их событийным наполнением географрическими активностями наглядно показывают это через постоянный диалог с детьми на равных, установление междисциплинарных связей, серьезную опытно-экспериментальную работу и активные методы обучения $[1,5]$.

Как отмечает один из экспертов, работников музея Мирового океана, основная миссия их музея в современном мире связана именно с просветительской и научно-образовательной деятельностью: "Я считаю, что музей должен занимать одно из ключевых мест в образовании, потому что здесь есть возложность реализовываться не только в каких-то узко заданньх ралках, это очень широкий спектр...".

Развивающий характер среды Музея Мирового океана основан, прежде всего, на разработанных технологиях различных типов для педагогических занятий в рамках музейных программ, имеющих разовый или циклический характер и дифференцированных по возрасту, как, например, "Один день в музее" [3].

В отличие от статичного сидения за партой в школе в музее дети активно перемещаются по экспозициям, меняют виды деятельности, как отмечает работник музея Мирового океана: "Мы переходим из одного зала в другой, используел наглядную инфборлацию, предметы, которые выставлены в экспозииионных залах".

Все это базируется на хорошей материально-технической базе, которую не может себе позволить школа. Из интервью с экспертом, работником музея: "У нас был проект "энергия глубины" по добыче неббти в нашел регионе, и мы создали совлестно с одной из фбирл солевую пещеру. У нас были найдень довольно хорошие залежи калиево-магниевых солей - очень редких, дорогостоящuх...".

Как отмечает эксперт, ребят привлекает сам формат занятий: "сала amмосбера привлекает, музей - это больше элоиии и впечатления, которые илеют значение. Часто мы не всполинаел инборлацию, которая обезличена, а всполинаел то, что вызвало у нас восторг, то, что нал приятно...".

Музей стимулирует интерес учащихся к геоградии и мотивирует их к самообразованию. Для небольшого количества детей сама площадка музея 
становится фрактором, способствующим увлечению географической наукой и оказывающим влияние на выбор будущей профрессии [2].

Выработанные направления деятельности музея, способствующие популяризации естествознания, основываются на әффективном использовании следующих ресурсов: расширенных возможностей музейных экспозиций; участия в проведении региональных праздников и фрестивалей; осуществлении партнерских проектов, сотрудничества с образовательными учреждениями; применении образовательных интерактивных технологий; работе компетентных и мотивированных к профессиональному и личностному росту музейных сотрудников, осуществляющих коммуникацию с детьми; разработанной многоуровневой системе по включению детей разных возрастов в многообразные формы деятельности и приобщения к музейной культуре. Это определяет специфические черты Музея Мирового океана как социокультурного института, выполняющего культурные, просветительские, социальные и образовательные фонкции [4].

Географическая школа также много делает для вовлечения детей и взрослых в поле социально-экономических и эколого-биологических проблем области. Как отмечают эксперты, в занятиях школы участвуют не только школьники, но и школьные учителя, родители, а также другие заинтересованные взрослые: "на эти лекиии даже приходят горожане, когда такая животрепешушая тела, касается побережья, наприлер, его состояния, или озеленение городское или какие-то историко-географические вопросы регионального такого плана. Приходят все желающие. Это фборлат научно-популярных лекиий" (руководитель географбиеской школь).

Преподаватели географической школы-участники опроса добавляли к двум основным задачам школы (популяризации географрических знаний и набора абитуриентов) "восполнение пробелов географического образования средней школы, расширение кругозора школьников в области географии", "профориентацию школьников - знакомство с практическими специальностями", "воспитание экологически грамотного и ответственного поколения", а также "воспитание творческой личности, способной к успешной самореализации в современном динамично изменяющемся мире, через целенаправленное приобщение к географической культуре".

А в качестве рекомендаций по повышению заинтересованности детей в занятиях в географической школе эксперты предлагали "больше практических выездных занятий", "больше работы на природе (если не на природе, то на улице)", "участие в научных конференциях, конкурсах, выставках, социально-ориентированных проектах, экологических акщиях".

Однако, как и все образовательные и научно-исследовательские учреждения, которые ведут работу с детьми, географическая школа испытывает сложности в организации выездных занятий, экскурсии и т.п.: "y нас тоже редко получаются выезды, потолу что трудно с транспортол. Но стараелся выезжать по области, экскурсия идёт в автобусе, на местности, какие-то занятия на местности, когда уже приезжаел - это конечно самое любилое, всегда автобус биткол" (руководитель геограббческой школь).

Географические характеристики Калининградской области как особенного субъекта РФ также вызывают у детей познавательный интерес: "эксклавность региона очень сильно влияет на развитие ребенка". Близость Балтийского моря, к примеру, простимулировала исследовательский проект школьников "Правила поведения на воде".

Учитель географии одной из школ г. Гвардейска рассказал о межшкольном обмене с немецкой школой г. Веттера, дающем возможности не только для расширения географических горизонтов школьников, но и стимулирующем интерес к познанию особенностей собственной территории: "Дети совершенствуют знания иностранных языков и узнают новые геограббиеские территории. Во вреля работы над проектали изучаются эколого-геограббческие вопрось, наприлер, "Малье реки моей Родиньь", "Экология Куршской косьь", "Леса Калининградской области" и др.".

География для детей имеет и вполне практический выход во взрослую жизнь через профориентационую работу со школьниками в рамках уроков географиии. Современные дети "не бредят подвигами полярников" еще и потому, 
что они - прагматики, их герои - люди, успешные в жизни, достигшие определенного положения в обществе.

\section{География детства: размышления участников исследования}

На основе собранных интервью школьников, студентов, учителей, работников музея мы может обозначить проблемное поле географоии детства как нового направления, специфику и тренды развития.

Почему география детства так актуальна. Само детство как этап и область исследовательского поиска выдвигает специфические проблемы и вопросы. "Детство - такое вреля, когда ты хочешь на луну полететь", - отмечает один из наших информантов. Учитель географии так определяет истоки направления: "Геограббия детства оттуда идет - из познания лира, каждый ребенок хочет чего-нибудь познать, вопросы задает - что тал за горизонтол, геограбби детства оттуда".

В рамках этого направления дети могут шире смотреть на мир, не замыкаться в своей стране, территории проживания. Так у детей формируется глобальность мышления, а у взрослых - способность воспринимать мир глазами ребенка

Учителя - участники четвертого геоградического фрестиваля подчеркивали, что детям интересна инфрормация о детях из других стран: "mельь, связанные с образованиел и культурой их сверстников, вызывают интерес у детей"; "не приполню тел, где бы говорилось в учебнике про детей, разве только в учебнике Крыловой О. В. про обучение детей в Австралии -очень яркое, короткое и елкое. Ил было интересно"; "Надо добавить про особенности обучения детей, систелу отлеток, увлечения. Буквально в 3-4-х предложениях, возложно в фборле слоганов, мелов, детских анекдотов, инфбограбби ки", "Можно ввести тель о качестве жизни детей в разных странах мира. Детство-какое оно? Веселое и беззаботное? Или тяжелое и голодное?".

Темами для географии детства были определены географические перемещения, туризм и путешествия, о которых надо рассказывать с точки зрения субъективного мнения детей, которое не всегда совпадает с мнением взрослых. Как считает один из әкспертов "интересно было бы сделать что-то в виде путешествий по разныли странал, связь с историей, потолу что большая проблела, что нестыковка идет, что нет междисииплинарной связи, вроде бы как бы отдельно это дается в окружающел мире, но это ббраглентарно".

Школьники - участники четвертого географрического фрестиваля в ходе анкетного опроса пофрантазировали на тему "Чем могла бы заниматься география детства": "восприятие науки ребенкол", "изленения, связанные с переездали и путешествияли", "такая наука пологла бь понять детял их будушую роль на планете и сделать их более ответственныли", "изучение географбии в раннел детстве".

Кроме того, география детства в оценках взрослых участников исследования связана с краеведением: "история, природа и географбия края, области, в которой вырос человек", а школьники проецируют краевой компонент на географию детства через "детские палятные места".

\section{Заключение \\ Перспективы современной географической науки}

На развитие географической науки в современном обществе оказывают влияние процессы, связанные с гуманизацией, глобализацией, экологизацией и информатизацией. Меняются ключевые задачи науки, появляются инновационные направления актуальных исследований, отражающие потребности, в том числе регионального развития, модифицируется научный географический дискурс.

Трансформации затрагивают и социализацию детей, а также институциональную структуру современного общества.

При существующих проблемах преподавания географии в школе, в том числе связанных с ограниченностью материально-технических возможностей и ресурсов, а также непопулярностью данного предмета среди учащихся, идет поиск альтернативных социальных институтов, берущих на себя функции расширения географических знаний и умений у детей и молодежи, повышения 
значимости и понимания сфер востребованности геоградии в повседневной жизни современного человека. Очевидно, что такими площадками становятся музеи с естественно-научной направленностью, осуществляющие работу с учителями, детьми-дошкольниками, школьниками и их родителями, а также вузы с соответствующими профильными направлениями.

Кейс Калининградской области показывает, что, несмотря на имеющиеся трудности и риски, примеры успешных практик в системе "школа-вуз-исследовательские структуры" по популяризации географрической науки в регионе среди детей и школьников демонстрируют Музей Мирового океана, Институт географии РАН, БФУ им. И. Канта. На наш взгляд, перспективы современной географической науки связаны с новыми междисциплинарными направлениями развития, в том числе связанными с детьми и ориентированными на детей, а также с региональным развитием и формирующейся в российских регионах системой взаимодействия традиционных образовательных и альтернативных социальных институтов, их взаимодействиями с производственными комплексами.

\section{Литература}

1. Антюфеева Т.В., Мардасова Е.В., Швецова Л.В. Опыт организации исследовательской работы учащихся школ по географии в вузе (на примере Алтайского государственного университета) // География в школе. 2018. № 4. С. 41-45.

2. Зубова О.Г. Музей Мирового океана как альтернативная образовательная площадка для популяризации естествознания для детей и молодежи. // Комплексные исследования детства. 2019. Том 1. № 3. C. 220-231 DOI: 10.33910/2687-0223-2019-1-4

3. Камерилова Г.С., Картавых М.А. Исследовательская деятельность в географрическом образовании школьников // География в школе. 2017. № 5, С. 4-13.

4. Кетова Л.М. Музейная педагогика как инновационная педагогическая технология //Человек в мире культуры. 2012 № 4, С. 76-81.

5. Низовцев В.А., Дмитрук Н.Г. Творческая деятельность школьников во внеурочной работе по географии // Географоя в школе 2019. № 2. С. 48-55.

6. Петрова Н.Н., Фадеева А.А. Методические пути достижения метапредметных результатов обучения географии // География в школе 2018. № 2. С. 55-63.

7. Страусс А. Основы качественного исследования : обоснованная теория, процедуры и техники / А. Страусс, Дж. Корбин; пер. с англ. и послесловие Т. С. Васильевой. М.: Эдиториал УРСС, 2001. 256 с.

8. Толвайшис Л., Филипова А.Г. География детства как новое исследовательское направление // Комплексные исследования детства. 2019. T.1. № 3. C. 167-173. DOI: 10.33910/2687-0223-2019-1-3-167-173

9. Федеральный государственный образовательный стандарт основного общего образования. М.: Просвещение. 2010

10. Федоров Г.М., Корнеевец В.С., Кузнецова Т.Ю., Часовский В.И. Россия в Балтийском регионе // География в школе. 2017. № 1. С. 4-13.

11. Филипова А.Г., Роготень Н.Н. От "Географии Для Детей" К "Географии Детства" // Известия Географрического общества Узбекистана. 2019. Т. 55. С. 137-141.

12. Хлебосолова О.А., Царева Л.А. Проблемы XXI века и географическое образование// География в школе 2018. № 7. С. 24-28.

13. Шилина И.Б. Внеклассная работа по географии. Методика обучения географии в общеобразовательных учреждениях: Учебное пособие для студентов вузов. Под ред. И.В. Душиной. М.: Дрофа. 2007. С. 477-487.

14. Aitken S. Children's Geographies: Tracing the Evolution and Involution of a Concept. // Geographical Review. 2018. Vol. 108 (1). pp. 3-23. DOI: 10.1111/gere.12289 (In English).

15. Alderson P., Morrow V. The ethics of research with children and young people: A practical handbook. London: Sage Publications Ltd, 2011. 176 p.

16. Bessell S., Evans R, Holt L. (eds) Rights-based research with children: principles and practice. Methodological Approaches. Geographies of Children and Young People. Singapore: Springer. 2015.

17. Children, nature, cities Ed. by Ann Marie F. Murnaghan and Laura J. Shillington. London, Routledge. 2016.

18. Freeman C. Twenty-five years of children's geographies: a planner's perspective. // Children's Geographies. 2020 Vol.18 (1) pp. 110-121 https://doi.org/10.1080/14733285.2 019.1598547

19. Hackett A., Holmes R., MacRae C., Procter L. Young children's museum geographies: spatial, material and bodily ways of knowing. // Children's Geographies. 2018. Vol.16 (5). pp. 481-488 https://doi.org/10.1080/14733285.2018.1497141 
20. Horton J., Kraftl P. What else? Some more ways of thinking and doing "Children's Geographies". // Children's Geographies. 2006. 4(1). p. 69-95 https://doi. org/10.1080/14733280600577459

21. Nairn K., Kraftl P. Introduction to Children and Young People, Space, Place, and Environment. Geographies of Children and Young People 3. Space, Place, and Environment. Singapore: Springer. 2016. 1-24.

22. Philo C. Childhood is measured out by sounds and sights and smells, before the dark of reason grows: children's geographies at 12. // Children's Geographies. 2016. Vol. 14 (6). pp. 623-640 https://doi.org/10.1080/14733285.2016.1187896

23. Pike S. Irish primary school children's definitions of "geography".//Irish Educational Studies. 2006. 25 (1). P. 75-91. DOI https://doi.org/10.1080/03323310600597618

24. Porter G., Townsend J., Hampshire K. Children and young people as producers of knowledge. // Children's Geographies. 2012.Vol. 10 (2) pp. 131-134 https://doi.org/10.1080 /14733285.2012.667915

25. Sack D, Petersen JE Children's attitudes toward geography: A Texas case study. // Journal of geography. 2007. 97 (3). P. 123-131. DOI: 10.1080/00221349808978836

26. Van Blerk L. Where in the world are youth geographies going? Reflections on the journey and directions for the future. // Children's Geographies. 2019. Vol. 17 (1). P. 32-35 DOI: 10.1080/14733285.2018.1535695 (In English).

27. Whitzman, C., and D. MizrachiCreating Child-Friendly High-Rise Environments: Beyond Wastelands and Glasshouses. // Urban Policy and Research. . 2012. 30 (3). P. 233249. https://doi.org/10.1080/08111146.2012.663729.

\section{Транслитерация по ГОСТ 7.79-2000 Система Б}

1. Antyufeeva T.V., Mardasova E.V., SHvetsova L.V. Opyt organizatsii issledovatel'skoj raboty uchashhikhsya shkol po geografii v vuze (na primere Altajskogo gosudarstvennogo universiteta) // Geografiya v shkole. 2018. № 4. S. 41-45.

2. Zubova O.G. Muzej Mirovogo okeana kak al'ternativnaya obrazovatel'naya ploshhadka dlya populyarizatsii estestvoznaniya dlya detej i molodezhi. // Kompleksnye issledovaniya detstva. 2019. Tom 1. № 3. S. 220-231 DOI: 10.33910/2687-0223-2019-1-4

3. Kamerilova G.S., Kartavykh M.A. Issledovatel'skaya deyatel'nost' v geograficheskom obrazovanii shkol'nikov // Geografiya v shkole. 2017. № 5, S. 4-13.

4. Ketova L.M. Muzejnaya pedagogika kak innovatsionnaya pedagogicheskaya tekhnologiya //CHelovek v mire kul'tury. 2012 № 4, S. 76-81.

5. Nizovtsev V.A., Dmitruk N.G. Tvorcheskaya deyatel'nost' shkol'nikov vo vneurochnoj rabote po geografii // Geografiya v shkole 2019. № 2. S. 48-55.

6. Petrova N.N., Fadeeva A.A. Metodicheskie puti dostizheniya metapredmetnykh rezul'tatov obucheniya geografii // Geografiya v shkole 2018. № 2. S. 55-63.

7. Strauss A. Osnovy kachestvennogo issledovaniya : obosnovannaya teoriya, protsedury i tekhniki / A. Strauss, Dzh. Korbin; per. s angl. i posleslovie T. S. Vasil'evoj. M.: EHditorial URSS, 2001. $256 \mathrm{~s}$.

8. Tolvajshis L., Filipova A.G. Geografiya detstva kak novoe issledovatel'skoe napravlenie // Kompleksnye issledovaniya detstva. 2019. T.1. № 3. S. 167-173. DOI: 10.33910/2687-0223-2019-1-3-167-173

9. Federal'nyj gosudarstvennyj obrazovatel'nyj standart osnovnogo obshhego obrazovaniya. M.: Prosveshhenie. 2010

10. Fedorov G.M., Korneevets V.S., Kuznetsova T.YU., CHasovskij V.I. Rossiya v Baltijskom regione // Geografiya v shkole. 2017. № 1. S. 4-13.

11. Filipova A.G., Rogoten' N.N. Ot "Geografii Dlya Detej" K "Geografii Detstva" // Izvestiya Geograficheskogo obshhestva Uzbekistana. 2019. T. 55. S. 137-141.

12. KHlebosolova O.A., TSareva L.A. Problemy KHKHI veka i geograficheskoe obrazovanie// Geografiya v shkole 2018. № 7. S. 24-28.

13. SHilina I.B. Vneklassnaya rabota po geografii. Metodika obucheniya geografii v obshheobrazovatel'nykh uchrezhdeniyakh: Uchebnoe posobie dlya studentov vuzov. Pod red. I.V. Dushinoj. M.: Drofa. 2007. S. 477-487.

14. Aitken S. Children's Geographies: Tracing the Evolution and Involution of a Concept. // Geographical Review. 2018. Vol. 108 (1). rr. 3-23. DOI: 10.1111/gere.12289 (In English).

15. Alderson P., Morrow V. The ethics of research with children and young people: A practical handbook. London: Sage Publications Ltd, 2011. 176 p.

16. Bessell S., Evans R, Holt L. (eds) Rights-based research with children: principles and practice. Methodological Approaches. Geographies of Children and Young People. Singapore: Springer. 2015.

17. Children, nature, cities Ed. by Ann Marie F. Murnaghan and Laura J. Shillington. London, Routledge. 2016. 
18. Freeman C. Twenty-five years of children's geographies: a planner's perspective. // Children's Geographies. 2020 Vol.18 (1) rr. 110-121 https://doi.org/10.1080/14733285.2 019.1598547

19. Hackett A., Holmes R., MacRae C., Procter L. Young children's museum geographies: spatial, material and bodily ways of knowing. // Children's Geographies. 2018. Vol.16 (5). rr. 481-488 https://doi.org/10.1080/14733285.2018.1497141

20. Horton J., Kraftl P. What else? Some more ways of thinking and doing "Children's Geographies". // Children's Geographies. 2006. 4(1). r. 69-95 https://doi. org/10.1080/14733280600577459

21. Nairn K., Kraftl R. Introduction to Children and Young People, Space, Place, and Environment. Geographies of Children and Young People 3. Space, Place, and Environment. Singapore: Springer. 2016. 1-24.

22. Philo C. Childhood is measured out by sounds and sights and smells, before the dark of reason grows: children's geographies at 12. // Children's Geographies. 2016. Vol. 14 (6). rr. 623-640 https://doi.org/10.1080/14733285.2016.1187896

23. Pike S. Irish primary school children's definitions of "geography". // Irish Educational Studies. 2006. 25 (1). P. 75-91. DOI https://doi.org/10.1080/03323310600597618

24. Porter G., Townsend J., Hampshire K. Children and young people as producers of knowledge. // Children's Geographies. 2012.Vol. 10 (2) rr. 131-134 https://doi.org/10.1080/ 14733285.2012 .667915

25. Sack D, Petersen JE Children's attitudes toward geography: A Texas case study. // Journal of geography. 2007. 97 (3). R. 123-131. DOI: 10.1080/00221349808978836

26. Van Blerk L. Where in the world are youth geographies going? Reflections on the journey and directions for the future. // Children's Geographies. 2019. Vol. 17 (1). P. 32-35 DOI: 10.1080/14733285.2018.1535695 (In English).

27. Whitzman, C., and D. MizrachiCreating Child-Friendly High-Rise Environments: Beyond Wastelands and Glasshouses. // Urban Policy and Research. . 2012. 30 (3). P. 233249. https://doi.org/10.1080/08111146.2012.663729. 
Филипова А. Г., Зубова О. Г., Бухтиярова И. Н. От географии для детей к географии детства: кейс Калининградской области.

В современном мобильном мире возросло влияние географических факторов на человека. Соответственно усилилась роль географии как научной дисциплины, раскрывающей особенности пространственной организации жизни общества. За рубежом активно развивается междисциплинарная отрасль знания - география детства, изучающая особенности взаимодействия детей и пространства. В статье рассмотрен кейс Калининградской области как региона, стимулирующего географические исследования, приращение географического знания. Традиционно ведущие отрасли экономики и активное развитие туризма в этом регионе определяют потребность в соответствующих специалистах, географической грамотности населения, а также в формировании географических компетенций у подрастающего поколения. В статье на примере учреждений и практик популяризации географических знаний в Калининградской области рассмотрен переход от географии для детей к географии детства. Данный переход обозначил перенос акцентов на субъектную роль ребенка, его активную позицию в географическом пространстве, важность учета его потребностей и представлений об окружающем мире как на уроках географии, так и в детско-взрослых взаимодействиях.

Ключевые слова: география детства, популяризащия географической науки, региональное развитие, преподавание географии

Filipova A. G., Zubova O. G., Bukhtiyarova I. N. From geography for children to the geography of childhood: Case study of the Kaliningrad region.

The article examines the transition from geography for children to the geography of childhood using the example of institutions and practices to popularize geographic knowledge in the Kaliningrad region. Traditionally, the leading sectors of the economy and the active development of tourism in this region determine the need for appropriate specialists, geographical literacy of the population, as well as in the formation of geographical competencies in the younger generation.

Key words: geography of childhood, popularization of geographical science, regional development, teaching geography

Для цитирования: Филипова А. Г., Зубова О. Г., Бухтиярова И. Н. От географии для детей к географии детства: кейс Калининградской области // Ойкумена. Регионоведческие исследования. 2021. № 4. C. 87-98. DOI: 10.24866/1998-6785/2021-4/87-98

For citation: Filipova A. G., Zubova O. G., Bukhtiyarova I. N. From geography for children to the geography of childhood: Case study of the Kaliningrad region // Ojkumena. Regional researches. 2021. № 4. P. 87-98. DOI: 10.24866/1998-6785/2021-4/87-98 